THE EUROPEAN JOURNAL OF LIFE WRITING VOLUME VII(2018)CP51-CP56

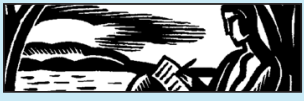

\title{
The Autobiographical Pact, Forty-Five Years Later
}

\section{Carole Allamand}

Philippe Lejeune is often credited with having defined autobiography, a compliment as impressive as it is, quite simply, unfair. For one thing, in spite of his protest, the much-quoted "retrospective narrative in prose that someone makes of his own existence..." is still widely mislabeled as "Lejeune's definition" of autobiography. ${ }^{1}$ It is in fact Larousse's, and was only meant to serve as a basis for "the autobiographical pact," Lejeune's true contribution to the study of life writing. ${ }^{2}$

Still, this concept coined in 1971 is anything but Lejeune's last word on the matter. In the twenty-one books that followed the publication of his famous article in Poétique, the pact received many amendments as its author's take on referentiality became more intricate. "The image of the formalist definer that 'The Autobiographical Pact' gives of me strikes me as partial,"4 Lejeune notes in an analysis of his 1973 article. Indeed, Structuralist theory was only a brief moment in his career, another perspective on a practice that Lejeune has apprehended as an historian, literary critic, and archivist. A deeply informed reader, Lejeune didn't limit himself to the canon either, and broke new ground in other media-photography, cinema, the diary, the Internet... - as well as the world of unpublished or self-published autobiographers. His legacy as France's most eminent specialist of life writing is now secured by the Association pour l'Autobiographie et le Patrimoine Autobiographique, which he founded in $1992 .{ }^{5}$

"The most outspoken critics of Lejeune as a theorist of genre have not kept pace with the progressive sophistication of his development," ${ }^{6}$ Paul John Eakin rightly observed. The most outspoken critic of the "autobiographical pact," one might add, is without a doubt its creator, who analyzed its shortcomings in "The Autobiographical Pact (bis)" (1983) and "The Autobiographical Pact, Twenty-Five Years Later" (2002). In between, a series of articles - unfortunately, not all translated-bear witness to 
the evolution of Lejeunian thought on the following key statements made in his 1973 article:

- "Identity is the real starting point of autobiography"

- "The deep subject of autobiography is the proper name"

- "The autobiographical genre is a contractual genre"

In the boom years of Deconstruction, the first statement was bound to meet with resistance, and it did. A reviewer for the American journal Diacritics deemed the crux of the autobiographical pact (the identity of the author, narrator, and character) "antediluvian," and called Lejeune an "idealist." ${ }^{8}$ Critics such as Paul de Man, Michel Beaujour, and Serge Doubrovsky, to name a few, concluded that its author got things backwards, mistaking as autobiography's "starting point" what was in fact its unreachable horizon. ${ }^{9}$ As if mesmerized by the prickly term of identity, readers of the "Autobiographical Pact" were quick to lend a psychological or existential meaning to a word that Lejeune explicitly uses in a logical sense. His definition of autobiography, he insists, does not imply a hypothetical subjective unity, "the being-in-itself of the past," but "beingfor-itself, manifested in the present of the enunciation."10 To understand this distinction fully, one must recall the premise of the 1973 article, and its radical departure from Lejeune's earlier work (L'Autobiographie en France, 1971), in which he treated referentiality as a textual problem. What makes "The Autobiographical Pact" so innovative is its treatment of reference as a question of reading, not writing. The exact nature of the identity between author, narrator and character is thus irrelevant to Lejeune, who seeks to know instead how such an identity can be conveyed to, and conceived by, readers of self-referential narratives. While it would be an exaggeration to say that Lejeune entirely avoided the question of subjectivity, or the autobiographical "I," his conception of it is much less naïve than it was made to sound overseas. Even before the "Pact," Lejeune referred to the "ego" as "one of the great myths of modern civilization,"11 and his 1973 article envisions that the self might be a creation of language. ${ }^{12}$ Expanding on this idea, his second anthology of articles, Je est un autre, ${ }^{13}$ deeply problematizes the identity that the autobiographical pact is supposed to seal.

Lejeune's critique of the subject, however, did not lead him to the same conclusion as many theorists of his time, who viewed the aporia of the subject as proof of its non-existence, and in some cases extended this verdict to autobiography itself. Indeed, when Lejeune writes that "the impossibility of autobiography doesn't prevent it from existing," ${ }^{4}$ or when he confesses that "[he] believes in the Holy Spirit of the first person," 15 he is not taking the easy way out, but pointing to the performative dimension 
of self-representation and self-conception that sets his theory apart from those of others. Just as fictions, fantasies, or myths are no less real to the consciousness than memories, impressions, or abstract ideas, the autobiographical pact owes as much to desire and denial as it does to the quest for authenticity. Readers who kept pace with Lejeune's work are well aware that his notion of identity has gradually evolved into what Paul Ricœur labeled "narrative identity," or the process of storytelling-not to be confused with fiction-making - by which individuals achieve a sense of unity, or self. ${ }^{16}$

As the "autobiographical pact" spurred new discussions, Lejeune seized an opportunity to fine-tune his definition, reassessing and at times reinforcing its components, as is the case with the question of the proper name, and the pact itself. There has been abundant commentary on Serge Doubrovsky's reaction to the 1973 article, which resulted in the invention of the genre of autofiction. Although this (not so) new genre left Lejeune largely unimpressed, reflecting on Doubrovsky's Fils led him to realize that proper names do not just authenticate a text from the outside, as mere referents, but operate from within the narrative by eliciting the reader's credence. "Real names," he writes, "possess a sort of magnetic force, and convey an aura of truth to everything that comes close to them." "17 Just as the phrase "Once upon a time..." defuses belief, the name of an existing person activates it, no matter how fictional his or her story may be. In this sense, the proper name really is the deep subject of autobiography.

Elizabeth W. Bruss' intervention was perhaps even more important to the evolution of the autobiographical pact. Her seminal article on "autobiographical acts,"18 published in Poétique a year after Lejeune's "Pact," resonated with his desire to define autobiography from a reader's standpoint and thereby challenge the dominant discourse on literary genres. Integrating Bruss' Searlian approach to communication with the views of H.R. Jauss about the reader's horizons of expectations, Lejeune made a compelling case for genres as modes of reading in his 1975 article on autobiography and literary history. Bruss' objection to the possibility of a contract between parties, i.e. authors and readers, who don't share an institutional context also motivated Lejeune to reevaluate his stance on the contractual nature of autobiography, which he admitted to having "overvalued." ${ }^{19}$ Coming back to his earlier claim that autobiography is formally indistinguishable from fiction, he eventually recognized that textual properties (i.e. autodiegetic narration, the presence of biographical facts, etc.) were required if his pact is to function. Two articles written in 1987- "Does Autobiography Exist?" and "Is it Possible to Innovate in Autobiography?" - testify to his dynamic conception of autobiography as a "generic force" depending on the complex interplay of textual and 
contextual elements. ${ }^{20}$ After replacing it with the more neutral idea of "commitment," Lejeune was thus led to rehabilitate his pact, which he does in "The Autobiographical Pact, Twenty-Five Years Later," arguing that a "pact" is precisely not a contract, but a performative act befitting the pragmatic nature of the autobiographical transaction.

This brings us back to the opening question of "The Autobiographical Pact": "Is it possible to define autobiography?" Lejeune would no doubt admit that it may not be, and gladly: "What is wonderful with the field of autobiography," he wrote in a postscript to his best-known article, "is that one can always do something else without leaving it. This is what I could have told the friend who, after The Pact, suggested that I change genres and study the epic or the sonnet." ${ }^{11}$

\section{WORKS CITED}

Beaujour, Michel. "Autobiographie et autoportrait." Poétique 32 (1977): 442-458.

Bruss, Elizabeth. "L'autobiographie considérée comme acte littéraire" (transl. J.-P. Richard). Poétique 17 (1974): 14-26.

Eakin, Paul John. "Philippe Lejeune and the Study of Autobiography." Romance Studies 8 (1986): 1-14.

Lejeune, Philippe. L'Autobiographie en France. Paris: Armand Colin, 1971.

Lejeune, Philippe. "Le pacte autobiographique." Poétique 14 (1973): 137-162.

Lejeune, Philippe. "Autobiographie et histoire littéraire." Le Pacte autobiographique. Paris: Seuil, 1975. 311-341. ["Autobiography and Literary History." On Autobiography, transl. K. Leary, ed. P.J. Eakin. Minneapolis (MN): U. of Minnesota Press, 1989. 141-161].

Lejeune, Philippe. "L'autobiographie à la troisième personne." Je est un autre. Paris: Seuil, 1980. 32-59. ["Autobiography and the Third Person," transl. A. and E. Tomarken. New Literary History 9 (1977): 27-50].

Lejeune, Philippe. "Le pacte autobiographique (bis)." Moi aussi. Paris: Seuil, 1986. 13-35. ["The Autobiographical Pact (bis). On Autobiography, transl. K. Leary, ed. P.J. Eakin. Minneapolis (MN): U. of Minnesota Press, 1989. 119-137].

Lejeune, Philippe. "Autobiographie, roman et nom propre.” Moi aussi. Paris: Seuil, 1986. $37-72$.

Lejeune, Philippe. "Peut-on innover en autobiographie?" L'Autobiographie. Paris: Les Belles Lettres, 1987. 67-100.

Lejeune, Philippe. "L'autobiographie existe-t-elle?" Biographie et Autobiographie au XXe siècle, Cahiers de l'Institut d'études germaniques. Montpellier: Université Paul Valéry, 1988. 81-94.

Lejeune, Philippe. "Postface." Le Pacte autobiographique (nouvelle édition augmentée). Paris: Seuil, 1996. 356-368.

Lejeune, Philippe. "Un siècle de résistance à l'autobiographie." Pour l'autobiographie. Paris: Seuil, 1998. 11-25.

Lejeune, Philippe. "Le pacte autobiographique, vingt-cinq ans après." Signes de vie. Paris: Seuil, 2005. 11-35.

Lejeune, Philippe. "Autobiographie et fiction.” Signes de vie. Paris: Seuil, 2005. 37-44.

Lejeune, Philippe. "Autobiographie et poésie." Signes de vie. Paris: Seuil, 2005. 45-62.

Man, Paul (de). "Autobiography as De-Facement." MLN94.5 (1979): 919-930.

Ricœur, Paul. Soi-même comme un autre. Paris: Seuil, 1996. 
Ricœur, Paul. "La vie: un récit en quête de narrateur." Ecrits et conférences I. Autour de la psychanalyse. Paris: Seuil, 2008. 257-276.

Ryan, Michael. "Self-Evidence." Diacritics 10.2 (1980): 2-16.

\section{ABOUT THE AUTHOR}

Carole Allamand teaches $20^{\text {th }}$ and $21^{\text {st }}$-century French literature at Rutgers University. She recently published a critical edition of Lejeune's "Autobiographical Pact" (Le "Pacte" de Philippe Lejeune ou l'autobiographie en théorie, Paris: Honoré Champion, 2018).

\section{NOTES}

1 "I am troubled when someone speaks of the definition of autobiography according to Philippe Lejeune; my definition is that of all good dictionaries, I took it from Larousse..." "Le pacte autobiographique, vingt-cinq ans après." Signes de vie. Paris: Seuil, 2005, 21. (My translation, unless otherwise mentioned).

2 It was a way, explains Lejeune, to "launch an analytical deconstruction of the factors that contribute to the perception of the [autobiographical] genre." "Le pacte autobiographique (bis)." Moi aussi. Paris: Seuil, 1986, 15. With the exception of "The Autobiographical Pact", I will refer to the French version of Lejeune's works.

3 Lejeune, Philippe. "Le pacte autobiographique." Poétique 14 (1973): 137-162. The article was reprinted in Le Pacte autobiographique (Paris: Seuil, 1975, 13-46). To avoid confusion, I will refer to the article as "the Pact", and to its key concept without capital letter or quotation marks.

4 "Le pacte (bis)", 32.

5 http://autobiographie.sitapa.org.

6 Eakin, Paul John. "Philippe Lejeune and the Study of Autobiography." Romance Studies 8 (1986): 7.

7 These articles are:

- "Autobiographie et histoire littéraire" (1975)

- "L'autobiographie à la troisième personne" (1977)

- "Autobiographie, roman et nom propre" (1984)

- "L'autobiographie existe-t-elle?" (1987)

- "Peut-on innover en autobiographie?" (1987)

- "Un siècle de résistance à l'autobiographie" (1994)

- "Postface" (1996)

- "Autobiographie et fiction" (2002)

- "Autobiographie et poésie" (2002).

8 Ryan, Michael. "Self-Evidence." Diacritics 10.2 (1980): 2-16.

9 "For the autobiographer," Serge Doubrovsky writes, "as for all writers, nothing, not even their own life, exists before the text." "L'initiative aux maux. Écrire sa psychanalyse," Cahiers Confrontation 1 (1979): 105. Similar arguments are made by Paul de Man in "Autobiography as De-facement," MLN 94.5 (1979): 920, and by Michel Beaujour in "Autobiographie et autoportrait," Poétique 32 (1977): 451.

10 "The Autobiographical Pact", 25.

11 L'Autobiographie en France. Paris: Armand Colin, 1971, 25. 
12 " $[\mathrm{T}]$ he idea crosses the minds of even the most naive of us that it is not the individual who defines the 'I,' but perhaps the 'I,' the individual, that is to say, the individual exists only in discourse." "The Autobiographical Pact", 9.

13 Je est un autre. Paris: Seuil, 1980.

14 "L'autobiographie a beau être impossible, ça ne l'empêche nullement d'exister." "Le pacte (bis)", 31.

15 "Le pacte (bis)", 30.

16 See Lejeune, "Autobiographie et fiction," Signes de vie. Paris: Seuil, 2005, 38-39, and "Le pacte autobiographique, vingt-cinq ans après," op. cit., 17.

17 "Autobiographie, roman et nom propre," 67.

18 Bruss, Elizabeth W., "L'autobiographie considérée comme acte littéraire" (transl. J.-P. Richard). Poétique 17 (1974): 14-26.

19 "Le pacte (bis)", 30.

20 "L'autobiographie existe-t-elle ?" and "Peut-on innover en autobiographie ?"

21 Lejeune, Philippe. "Postface." Le Pacte autobiographique ( $2^{\text {nd }}$ ed.). Paris: Seuil, 1996, 367. 